ЗАСТОСУВАННЯ ПРИНЦИПІВ ҐЕНДЕРНОЇ РІВНОСТІ ПІД ЧАС ПЛАНУВАННЯ БЮДЖЕТНИХ ВИДАТКІВ ТА ДОХОДІВ В УКРАЇНІ APPLICATION OF THE PRINCIPLES OF GENDER EQUALITY
IN THE PLANNING OF BUDGET EXPENDITURE AND INCOME IN UKRAINE

УДК 336.143

https://doi.org/10.32843/bses.64-22

\section{Приймак I.I.}

к.е.н., доцент,

доцент кафедри фрінансів,

грошового обігу і кредиту

Львівський національний університет

імені Івана Франка

Мунтян I.B.

магістрантка

Львівський національний університет

імені Івана Франка

\section{Pryimak Iryna}

Ivan Franko National University of Lviv Muntian Iryna

Ivan Franko National University of Lviv

\begin{abstract}
У статті з'ясовано сутність та переваги ґендерно-орієнтованогобюджетування. Проаналізовано показники ґендерної статистики, зокрема міста Львова, такі як структура постійного населення за статтю, рівень безробіття населення за віковими групами та статтю, показники смертності за причинами та статтю, соціальні групи населення внутрішньо переміщених осіб (ВПО) та проблеми, з якими вони найчастіше стикаються залежно від статі. Проведено кореляційний аналіз ґендерного впливу на податкові надходження бюджетів на основі показників, які безпосередньо впливають на податкові надходження до бюджетів із розподілом за статями: середньомісячних заробітних плат жінок та чоловіків в Україні за період 2012-2019 рр., а також кількості жінок та чоловіків ФОП та їхніх доходів за період 20162020 pp. Оцінено вплив зазначених показників на фрормування доходного та витратного складників бюджету за результатами їx статистичного та кореляційного аналізу. Ключові слова: ґендерно-орієнтоване бюджетування, державні фінанси, бюджет, місчеві бюджети, ґендерна рівність.
\end{abstract}

В статье выяснены сущность и преимущества гендерно-ориентированного бюд- жетирования. Проанализированы показатели гендерной статистики, в частности города Львова, такие как структура постоянного населения с учетом пола, уровень безработицы населения по возрастным группам и полу, показатели смертности в зависимости от причин и пола, социальные группы населения внутренне перемещенных лиц (ВПЛ) и проблемы, с которыми они чаще всего сталкиваются в зависимости om пола. Проведен корреляционный анализ гендерного воздействия на налоговые поступления бюджетов на основе показателей, которые непосредственно влияют на налоговые поступления в бюджеты с распределением по полу: среднемесячных заработных плат мужчин и женщин в Украине за период 2012-2019 г2., а также количества женщин и мужчин ФЛП и их доходов за период 2016-2020 г2. Оченено влияние указанных показателей на фрормирование доходной и расходной составляющих бюджета по результатам их статистического и корреляционного анализа.

Ключевые слова: гендерно-ориентированное бюджетирование, государственные финансы, бюджет, местные бюджеты, гендерное равенство.

The article clarifies the essence and benefits of gender-oriented budgeting. The problem of lack of legislative consolidation of the use of GOB in the budget process is considered, which is one of the main reasons for slowing down the process of implementation of this method and approval of methods for its implementation. Indicators of gender statistics, in particular the city of Lviv, such as the structure of the permanent population by gender, unemployment rate by age and gender, mortality rates by cause and gender, social groups of internally displaced persons (IDPs) and the problems they most often face depending on gender are analyzed. It was found that the situation of women in most areas is worse than men, and in modern conditions during the pandemic situation only gets worse. Given recent world events, the need for a public financial management system that takes into account the impact of gender measures to overcome the coronavirus pandemic is justified. A correlation analysis of gender impact on tax revenues of budgets on the basis of indicators that directly affect tax revenues to budgets by gender such as the average monthly wages of women and men in Ukraine for the period 2012-2019, as well as the number of women and men PE and their income for the period 2016-2020 has been conducted. The reasons for the reported results of the analysis are substantiated and explained, taking into account all possible factors. It is clear how the closure of "sleeping" private enterpreneurs, which has been observed since 2016, has affected the indicator of the total number of private enterpreneurs and their income indicators, which directly affect tax revenues to local budgets. The influence of these indicators on the formation of revenue and expenditure components of the budget based on the results of their statistical and correlation analyzes is estimated. The article confirms the opinion that the results of gender budget analysis help to make decisions on the directions of budget policy and development of industries in the future, taking into account the needs of men and women from different groups. As a result, it makes it possible to eliminate inequality in access to services financed from the local budget in the indicated areas.

Key words: gender-oriented budgeting, public finances, budget, local budgets, gender equality.

Постановка проблеми. Ґендерно-орієнтоване бюджетування дедалі частіше застосовується у світовій практиці під час фоомування бюджетів, однак варто зазначити, що ефективно втілити цю методику важко навіть країнам із розвиненими системами бюджетного управління та 3 давніми традиціями захисту прав людини. На разі у світі не існує єдиної моделі ґендерного бюджетування, тому виникає можливість та необхідність побудувати в Україні свій власний унікальний підхід до застосування гендерного підходу в бюджетному управлінні. Звуження ґендерної нерівності дасть змогу збільшити продуктивність робочої сили та підвищити економічне зростання, а також може стати потужним чинником зростання бюджетних доходів. Аналіз впливу бюджетних рішень на ґендерну рівність має бути рефлексом вітчизняних економістів, політиків та державних службовців. Перші кроки для цього зроблені завдяки проєкту «Ґендерне бюджетування в Україні», який було реалізовано за підтримки Шведського агентства міжнародного розвитку та співпраці (SIDA).

Аналіз останніх досліджень і публікацій. Застосування принципів гендерної рівності у процес формування бюджетних програм, оцінка ґендерного впливу на виконання бюджетів $€$ досить новими для нашої держави. Упродовж останніх років низка українських науковців активно досліджувала сутність, необхідність та особливості застосування ґендерно-орієнтованого підходу 
в бюджетному процесі. Зокрема, заслуговують на увагу дослідження Т. Коляди [1], де розкрито переваги та проблеми застосування гендерного бюджетування як бюджетування, орієнтованого на результат, а також Г. Даудової і Т. Таукешевої [2], в якому розглянуто сутність та принципи побудови ґендерного бюджету. 3 огляду на досить вузьке коло вчених, які вивчають проблеми ґендерноорієнтованого бюджетування як інструменту, що дає змогу врахувати потреби та пріоритети жінок і чоловіків у процесі формування державного та місцевих бюджетів, сьогодні існують широкі можливості для наукових пошуків у цій сорері.

Постановка завдання. Мета статті - проаналізувати досвід застосування принципів ґендерної рівності під час планування бюджетних видатків та оцінити ґендерний вплив на фрормування доходів бюджетів в Україні, окреслити проблеми і запропонувати практичні рекомендації щодо скорочення ґендерної нерівності й удосконалення процесу запровадження ґендерного підходу в бюджетному процесі.

Виклад основного матеріалу дослідження. Сьогодні ще побутує твердження, що державні бюджети $є$ ґендерно нейтральними, тобто бюджетна політика має однаковий вплив і на чоловіків, і на жінок. Проте насправді потреби жінок і чоловіків дуже часто відрізняються, і якщо ігнорувати цю різницю у бюджетній політиці, це тільки посилюватиме існуючу соціальну нерівність.

Застосування ґендерно-орієнтованого підходу у бюджетному процесі $€$ одним із напрямів бюджетної реформи, що передбачена Стратегією ресрормування системи управління державними фрінансами на 2017-2021 рр. і реалізується Міністерством фрінансів у рамках удосконалення програмно-цільового методу.

У ході реалізації проєкту «Ґендерне бюджетування в Україні» експертами було розроблено концептуальні основи застосування гендерно чутливого бюджетування та визначено його сутність. Ґендерно-орієнтоване бюджетування (ҐОБ) - це застосування комплексного гендерного підходу в бюджетній політиці та бюджетному процесі на державному й місцевому рівнях, що включає розподіл бюджетних коштів за гендерним принципом, а також спричиняє посилення прозорості та підконтрольності [9].

Ґендерно-орієнтоване бюджетування - це спосіб бюджетування, у центрі якого конкретні люди - жінки та чоловіки з різних соціальних та демографрічних груп. Це набір різних інструментів, механізмів та інститутів, поєднаних спільною метою, внаслідок чого ґендерне управління стає одним з обов'язкових принципів національної політики та економіки. Ця концепція широко використовується багатьма міжнародними організаціями й $€$ способом зосередити увагу на інтересах людей у процесі фрормування та виконання національних бюджетів. Цей підхід доповнює інші бюджетні ресрорми та процеси вдосконалення, що проводяться урядами в усьому світі [12].

Попри низку переваг ґендерне бюджетування усе ще непопулярний метод у нашій країні через відсутність законодавчого закріплення його використання у бюджетному процесі. Це головна причина уповільнення процесу впровадження ґендерно-орієнтованого бюджетування та затвердження методів його реалізації. До переваг ґендерного бюджетування можна віднести:

- можливість оптимізації доходів і видатків бюджетів різних рівнів, ураховуючи ґендерні аспекти;

- підвищення якості послуг, гарантованих державою для населення, шляхом спрямування бюджетних витрат на потреби конкретного споживача;

- поліпшення законодавчого забезпечення 3 метою подолання наявних ґендерних проблем;

- підвищення темпів економічного розвитку територіальних громад 3 урахуванням більш ефективного використання наявних бюджетних ресурсів;

- скорочення проявів гендерної нерівності;

- сприяння формуванню та впровадженню ґендерно чутливої бюджетної політики;

- підвищення впливу суспільства (зокрема, жінок) на ухвалення управлінських рішень у бюджетному процесі.

Запровадження ґендерного бюджетування можна розглядати як необхідну умову дотримання рівних прав та можливостей чоловіків та жінок згідно з Конституцією України [1].

Основою застосування гендерного підходу в бюджетному процесі є гендерний аналіз бюджетних програм, важливим джерелом інформації для якого $€$ показники ґендерної статистики. Аналіз гендерної структури населення м. Львова та окремих соціальних груп дав можливість запропонувати напрями підвищення ефективності заходів, спрямованих на досягнення ґендерної рівності. У структурі населення міста Львова незначно переважають жінки (53\%). Кількість жіночого населення перевищує кількість чоловіків на 49,2 тис осіб [7]. Водночас для окремих соціальних груп існують суттєві дисбаланси. Наприклад, у Львові від безробіття страждають набагато більше жінок, аніж чоловіків, в усіх вікових групах, лише кількість безробітних чоловіків і жінок у віці 50-59 років приблизно однакова, хоча й тут лідирують жінки, хай і не зі значним відривом (рис. 1).

Якщо говорити про нинішню ситуацію з безробіттям в Україні загалом, а саме в період пандемії, то у карантинний період жінки і чоловіки отримували статус безробітних в однаковому кількісному співвідношенні, але чоловіків значно частіше пра- 
цевлаштовували, ніж жінок. Це можна пояснити як зменшенням кількості вакансій, так і тим, що сфрера обслуговування перебувала на карантині, а у ній більшою мірою працюють жінки [5].

Локдаун спричинив різке зростання частки економічно неактивних чоловіків - до 24\% (було 11\%). Економічно неактивних жінок до карантину було значно більше, ніж чоловіків, через кількість домогосподарок і тих, хто перебуває у декретній відпустці (29\%). Цей показник теж зріс, але не так різко (до 35\%). Це пояснюється тим, що більшість працюючих жінок зберегла місце роботи через специсріку «жіночих» і «чоловічих» професій. До традиційно «жіночих» сорер можна віднести медицину, освіту, роздрібну торгівлю, що продовжували функціонувати в період обмежень (у т. ч. освіта - дистанційно). У переліку «чоловічих» просресій - транспортна галузь, а вона, як відомо, була практично повністю зупинена в березні-травні 2020 р. Припускаємо, що деякі сім"ї могли опинитися повністю на утриманні жінок, які продовжили працювати у період локдауну.

Отже, незважаючи на те що чоловіки більше постраждали від економічної кризи в частині втрати роботи або заробітку, на жінок лягло істотне додаткове навантаження: більшість із них продовжила працювати, при цьому виконуючи ще більше домашніх обов'язків, у тому числі з догляду за дітьми.

Також зменшилася кількість зайнятих пенсіонерок та зросла кількість працюючих студенток. Припускаємо, що працівниці похилого віку, у яких не було можливості доїхати на роботу, могли ії втратити або, наприклад, піти у відпустку за влас- ний рахунок. Натомість для студенток, які є більш мобільними, з'явилося більше можливостей, наприклад вони могли працювати продавцями чи кур'єрами.

Загалом у понад половини як безробітних, так i зайнятих жінок вибірки є діти, що для кожної з них означає різке зростання навантаження внаслідок закритих дитсадків і шкіл, тому потрібно звернути увагу не лише на тих, хто став безробітним, а й на всі родини з малими дітьми [10]. Особливу увагу варто було б приділити, і не тільки у період пандемії, кількості та стану дитячих майданчиків та доріжок для прогулянок із дітьми. Реалізація громадських проєктів місцевих органів влади є одним із найреальніших шляхів у досягненні цієї мети.

Варто зазначити, що жінки, особливо жінки з найбільш уразливих груп (безробітні, жінки, які самотужки виховують власних дітей, жінки-інваліди, жінки похилого віку), найбільше страждають від економічних утрат та погіршення стану здоров'я. Для вдосконалення державних та місцевих бюджетних програм, спрямованих на підвищення зайнятості, необхідно: забезпечити фрормування статистики про підприємців за статтю та віком, оцінити вплив пандемії на зайнятість чоловіків та жінок, посилити проведення заходів щодо скорочення різниці в зарплаті за ґендерною ознакою, розробити державну програму підтримки розвитку жіночого підприємництва та надання відповідної інституційної допомоги, створювати додаткові можливості для працевлаштування жінок.

Серед пенсіонерів у цілому по Україні та зокрема у Львові переважають жінки. Так, станом на жовтень 2019 р. у Львові проживає 72\%

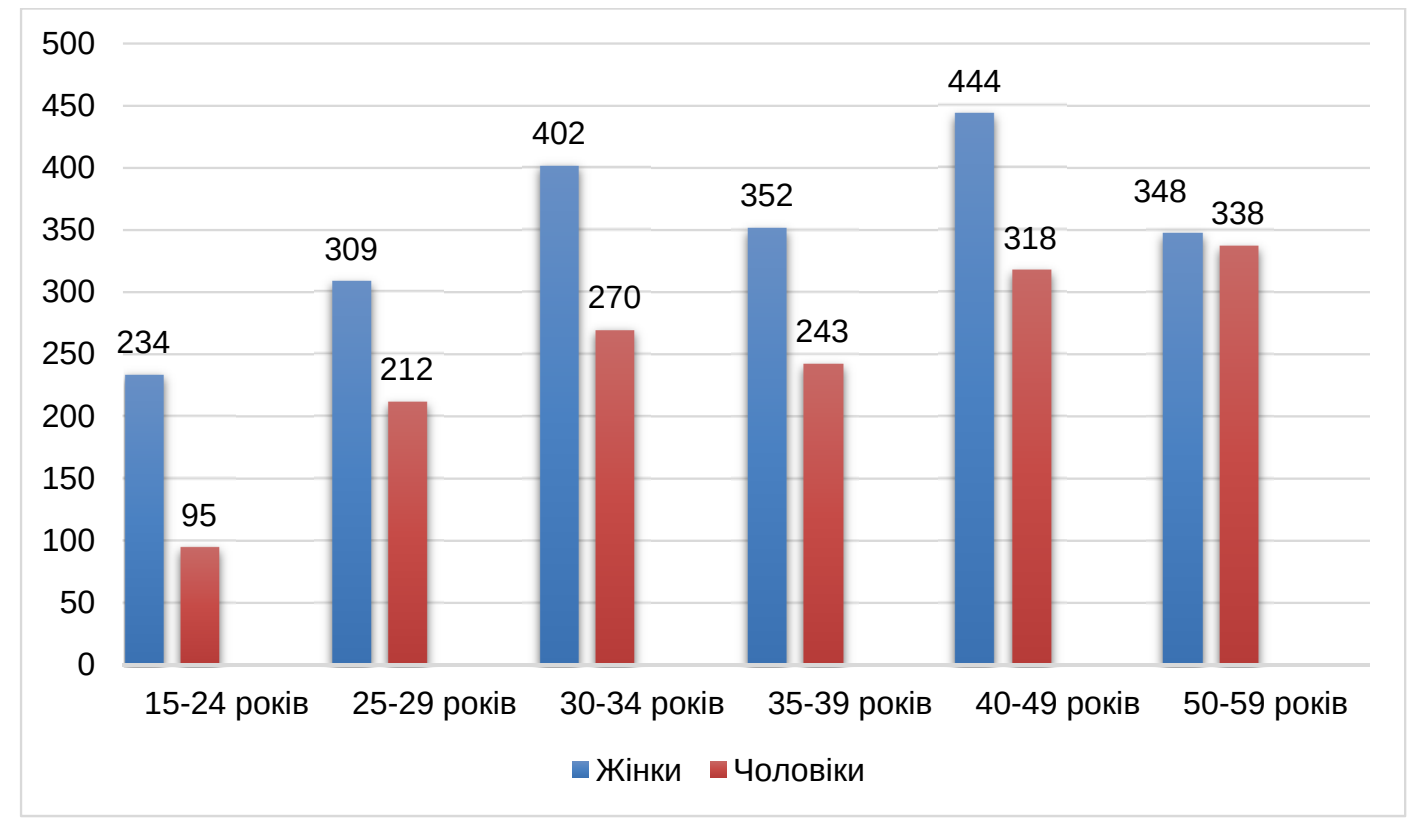

Рис. 1. Рівень безробіття населення м. Львова у жовтні 2019 р. за віковими групами та статтю

Джерело: складено за [7] 
пенсіонерів-жінок та 28\% пенсіонерів-чоловіків. Загалом у Львівській області хлопчиків зазвичай народжується більше: на 100 новонароджених дівчаток припадає 105 хлопчиків. Серед молоді віком 15-34 років на 100 дівчат припадає 104 хлопці, серед осіб старше 35 років на 100 жінок припадає 81 чоловік, і лише 53 чоловіки припадає на 100 жінок у віці 65 років і старше. Це зумовлено тим, що чоловіки живуть менше, ніж жінки, і частіше помирають [8].

У чоловіків ризик передчасної смерті набагато вищий, аніж у жінок. Різке зростання рівня смертності у чоловіків розпочинається у віці 40-44 років, тоді як у жінок - після 55-59 років. Найчастіше причинами смерті у чоловіків $€$ хвороби системи кровообігу (57 випадків на 100 померлих), новоутворення (15 випадків) та зовнішні причини (8 випадків). Серед зовнішніх причин найбільша кількість чоловіків загинула під час транспортних нещасних випадків - 248 осіб, або 18\% (рис. 2) [8].

Для зниження смертності як чоловіків, так і жінок перш за все необхідне проведення заходів, спрямованих на діагностику і вчасне виявлення хвороб систем кровообігу, отже, на такі заходи потрібно збільшити бюджетне фрінансування. Важливо також розширити фрінансування державних програм, спрямованих на раннє виявлення хвороб, поширених серед чоловічого населення. Наприклад, виділити кошти на придбання діагностичного обладнання.

Ще одним способом боротьби зі смертністю чоловіків може бути запуск рекламних кампаній, які заохочуватимуть чоловіків із молодого віку регулярно проводити діагностику власного здоров'я, аби запобігти пізньому виявленню хвороб, лікування яких на ранніх стадіях $€$ успішним. Корисними також будуть виступи медиків у ЗМІ, різні просвітницькі заходи. Раннє виявлення хвороб має значний вплив не тільки на шанс одужання, а й на обсяг та тривалість необхідного лікування, а отже, і на фрінансування лікувального процесу.

Російська агресія проти України призвела до ситуації, коли тисячі українців були змушені залишити власні домівки та облаштовувати своє життя
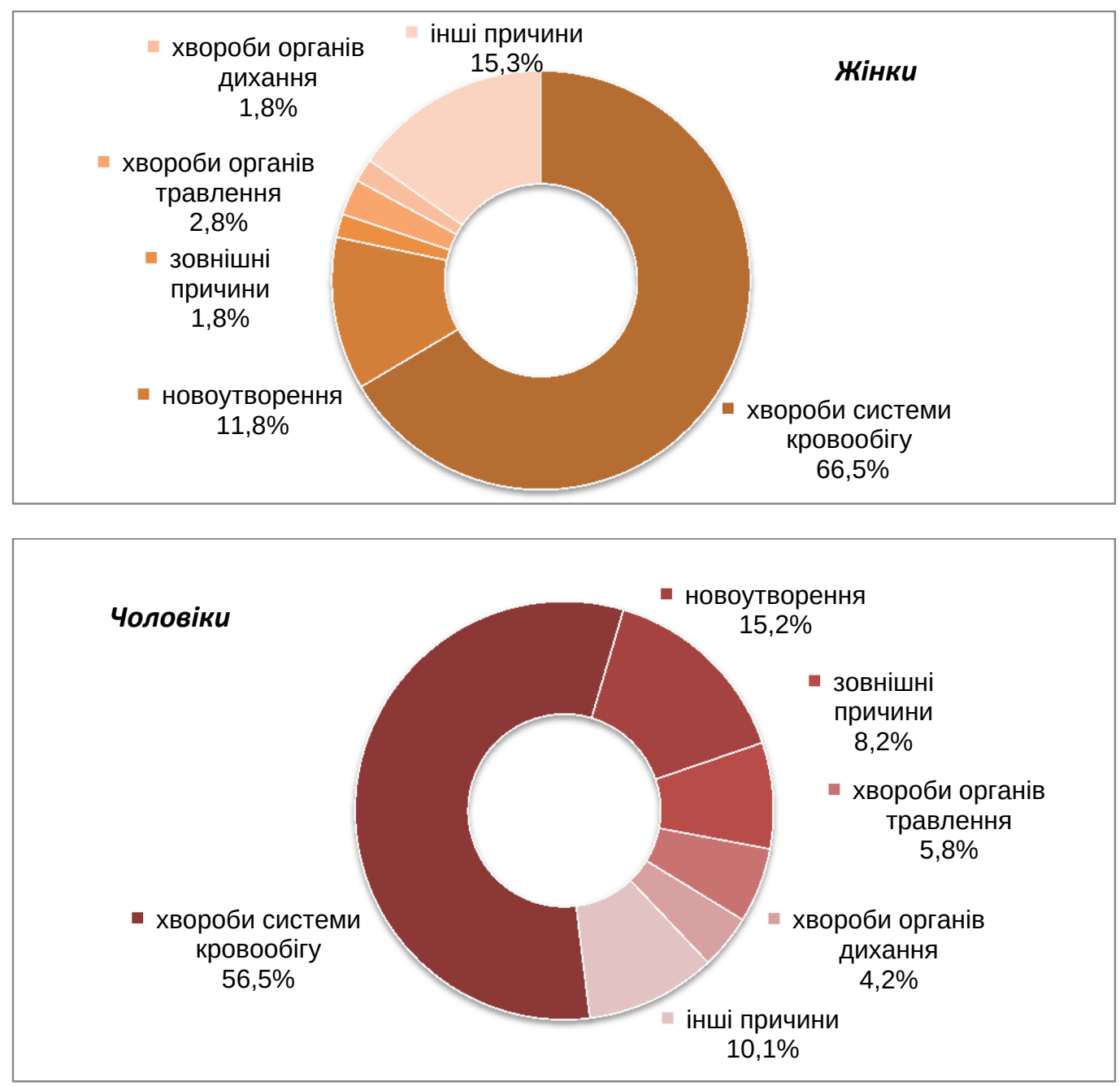

Рис. 2. Розподіл померлих за основними причинами у 2019 р., м. Львів

Джерело: складено за [3] 
у нових громадах. У Львові серед внутрішньо переміщених осіб (ВПО) 58\% жінок та 42\% чоловіків [7]. Хоча кількість жінок не суттєво, але переважає, проте ситуація з дотриманням їхніх прав не найкраща.

Насамперед, це стосується погано організованого процесу інтеграції жінок-переселенців у місцеві територіальні громади. А це, своєю чергою, $€$ порушенням їхніх прав на працевлаштування, житло, отримання соціальних і медичних послуг, здобуття освіти тощо. Для порівняння: рівень реалізації прав жінок-ВПО становить приблизно 10-12\% від реалізації прав чоловіків-ВПО, що підтверджує ґендерні перекоси [10].

Центр «Жіночі перспективи» провів ґендерний аналіз, який виявив, що існує ґендерна специфіка становища жінок-ВПО та чоловіків-ВПО. Ця специфріка зазвичай відтворює основні ґендерні проблеми соціуму в Україні, основою яких $€$ ґендерні ролі та ґендерні стереотипи.

Водночас кількість ґендерних стереотипів у середовищі ВПО значно вища, ніж в українському суспільстві загалом. Наприклад, дослідження засвідчує значно більшу «відповідальність» та додаткове навантаження щодо виховання неповнолітніх дітей на жінках-ВПО (27,1\% чоловіків проживає разом із дітьми до 18 років та 41,6\% жінок) - гендерний розрив 14,5\% [4]. Також жінки перебувають в економічно вразливішому стані: жінки-ВПО проживають із багатодітними родинами втричі частіше, ніж чоловіки, майже удвічі частіше - у малозабезпечених та на 9\% частіше проживають у сім'ях, які перебувають у складних життєвих обставинах.

Усуненню згаданих проблем, на нашу думку, сприятимуть такі заходи:

- посилення адресності надання державної соціальної підтримки найбільш незахищеним верствам населення (у тому числі ВПО) та контроль процесу її надання;

- надання цільової та належної фрінансової допомоги внутрішньо переміщеним жінкам, які втратили роботу під час карантину;

- проведення інорормаційних кампаній у приймаючих громадах для уникнення дискримінації, стигматизації та маргіналізації ВПО, особливо під час пандемії.

Ґендерне бюджетування можна використовувати під час планування як видаткової, так і доходної частини бюджетів. Однак проведення оцінки ґендерного впливу на доходи бюджетів - досить складний процес, адже ставки податків, які $є$ основою наповнення бюджетів, однакові для чоловіків та жінок. Також в Україні практично не проводять дослідження ґендерного впливу на орормування надходжень за такими податками, як податок на доходи фрізичних осіб та єдиний податок.

щоб дослідити дану проблему детальніше, було проведено кореляційний аналіз показників, які безпосередньо впливають на податкові надходження до бюджетів із розподілом за статями. У процесі аналізу гендерного впливу на фрормування надходжень бюджетів проведено оцінку залежності податкових надходжень до зведеного бюджету України від середньомісячних заробітних плат жінок та чоловіків за період 2012-2019 рр., а також залежність податкових надходжень до місцевих бюджетів від кількості жінок та чоловіків ФОП та їхніх доходів за період 2016-2020 рр.

Визначено, що коефріцієнт кореляції Фехнера для показників середньомісячної заробітної плати жінок та податкових надходжень до зведеного бюджету становить 0,75. Це означає, що існує сильна пряма залежність між даними показниками і за збільшення середньомісячної заробітної плати зайнятих жінок розмір сум податкових надходжень зростатиме Тоді як для показників середньомісячної заробітної плати чоловіків та податкових надходжень до зведеного бюджету коефіцієнт кореляції Фехнера становить 0,43. У цьому разі маємо дещо слабшу залежність порівняно із цим показником для середньомісячних зарплат жінок (рис. 3).

Отже, за наповнення державного бюджету більше відповідальні жінки, ніж чоловіки. Це передусім пов'язано з тим, що середньомісячна зарплата жінок, за даними Державної служби статистики, є вищою, а отже, і суми податків, сплачених до бюджету, більші. Можливими причинами такої різниці в залежностях доходів бюджету від жіночих і чоловічих зарплат $є$ те, що чоловіки в Україні частіше працюють неофріційно, а також велика частина чоловічого населення країни виїжджає на роботу за кордон.

щодо жінок, то більша їх частина зазвичай працевлаштована у державній сорері у галузях медицини та освіти, також значна частина жіночого населення працює в державних комунальних підприємствах, що за замовчуванням передбачає ооріційне працевлаштування.

Важливою статтею наповнення місцевих бюджетів є єдиний податок, який, виступаючи інструментом спрощеної системи оподаткування, дає можливість розвиватися малому бізнесу. На надходження єдиного податку до місцевих бюджетів впливає багато чинників, один із них - зміна кількості суб'єктів малого підприємництва в Україні.

В Україні жінки становлять 46,6\% від усіх підприємців, їхня кількість у січні 2021 р. становила вже 863455 осіб. Частка жінок-підприємців зростає кожного року (ще в 2016 р. їх було 44,8\%). У 2016 р. різниця між кількістю чоловіків та жінок ФОП становила 10,4\%, у 2020 р. - 7\%, у 2021 р. $6,7 \%[6]$

Для оцінки ґендерного впливу на сплату цього податку до бюджетів проведено кореляційний аналіз залежності між кількістю жінок - ФОП і чолові- 

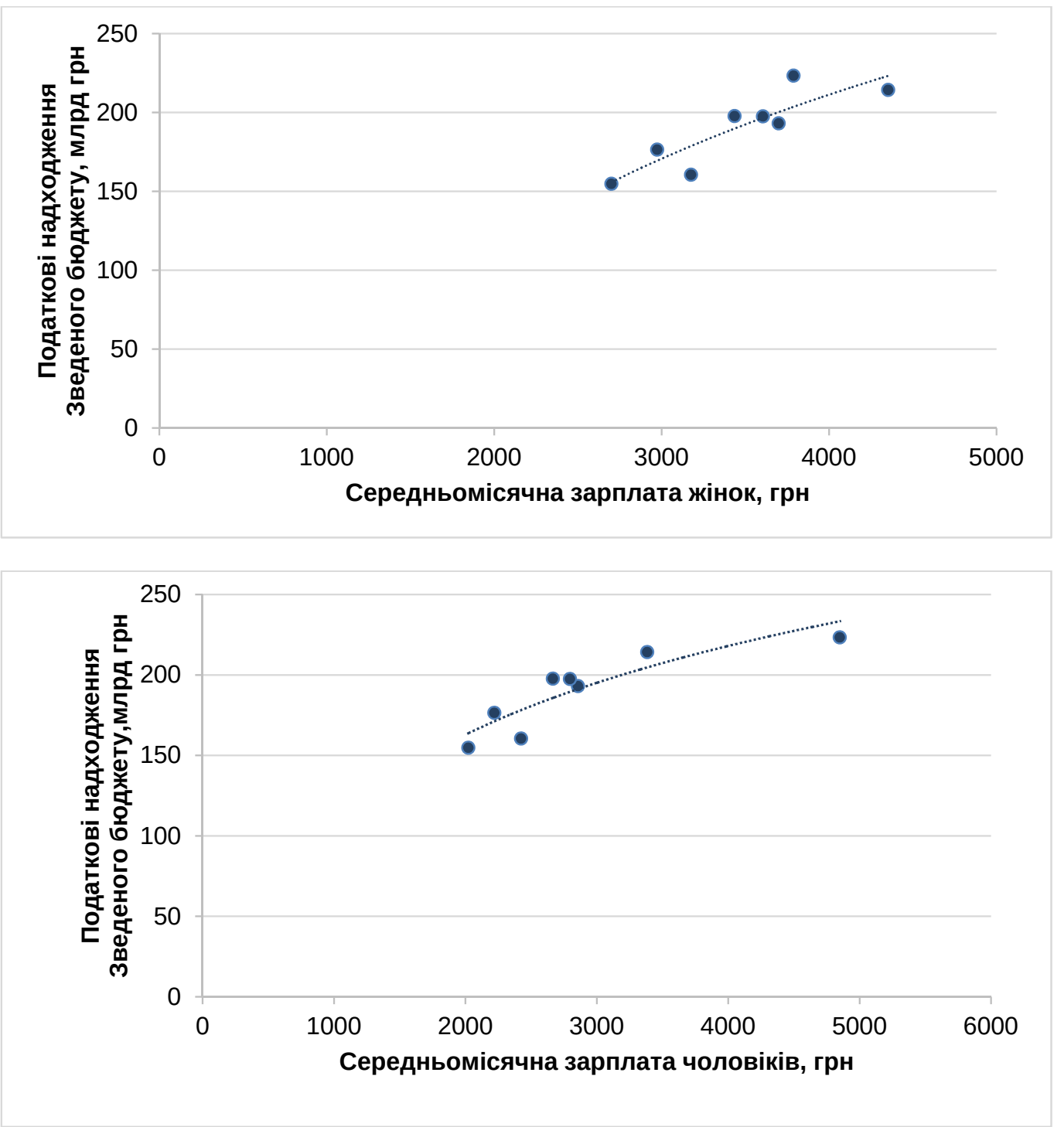

Рис. 3. Залежність величини податкових надходжень до зведеного бюджету України від величини середньомісячної заробітної плати жінок та чоловіків

Джерело: розраховано авторами

ків - ФОП та податковими надходженнями до місцевих бюджетів (рис. 4).

В обох випадках існує обернена залежність між показниками 3 коефіцієнтом -1. Це означає, що зі зменшенням кількості як жінок - ФОП, так і чоловіків - ФОП суми податкових надходжень до місцевих бюджетів зростають. Водночас якщо проаналізувати залежність доходів ФОП загалом із сумами податкових надходжень до місцевих бюджетів (рис. 5), можемо спостерігати пряму кореляційну залежність із коефіцієнтом кореляції, який за нашими розрахунками дорівнює одиниці, тобто доходи ФОП мають беззаперечний вплив на надходження до місцевих бюджетів, і зі зростанням доходів ФОП суми податкових надходжень до місцевих бюджетів теж зростають.

Причинами від'ємних кореляційних залежностей між кількістю жінок - ФОП і чоловіків - ФОП та податкових надходжень до місцевих бюджетів ми вважаємо закриття «сплячих» ФОП, яке можна було спостерігати 32016 р. Це суттєво вплинуло на показник загальної кількості ФОП, проте майже не вплинуло на показники їхніх доходів, які безпосередньо прямо впливають на податкові надходження до місцевих бюджетів.

Зростання темпу приросту єдиного податку до місцевих бюджетів із 2016 р., незважаючи на зменшення кількості суб'єктів малого підприємництва, можна пояснити впливом інфрляції, збільшенням бази оподаткування для I і II груп, підвищенням прожиткового мінімуму працездатних осіб і мінімальної заробітної плати, зростанням доходів платників III групи в абсолютному вираженні тощо.

Попри відсутність ґрунтовних досліджень гендерного впливу на доходи державного та місцевих бюджетів, уважаємо, що його вивчення 

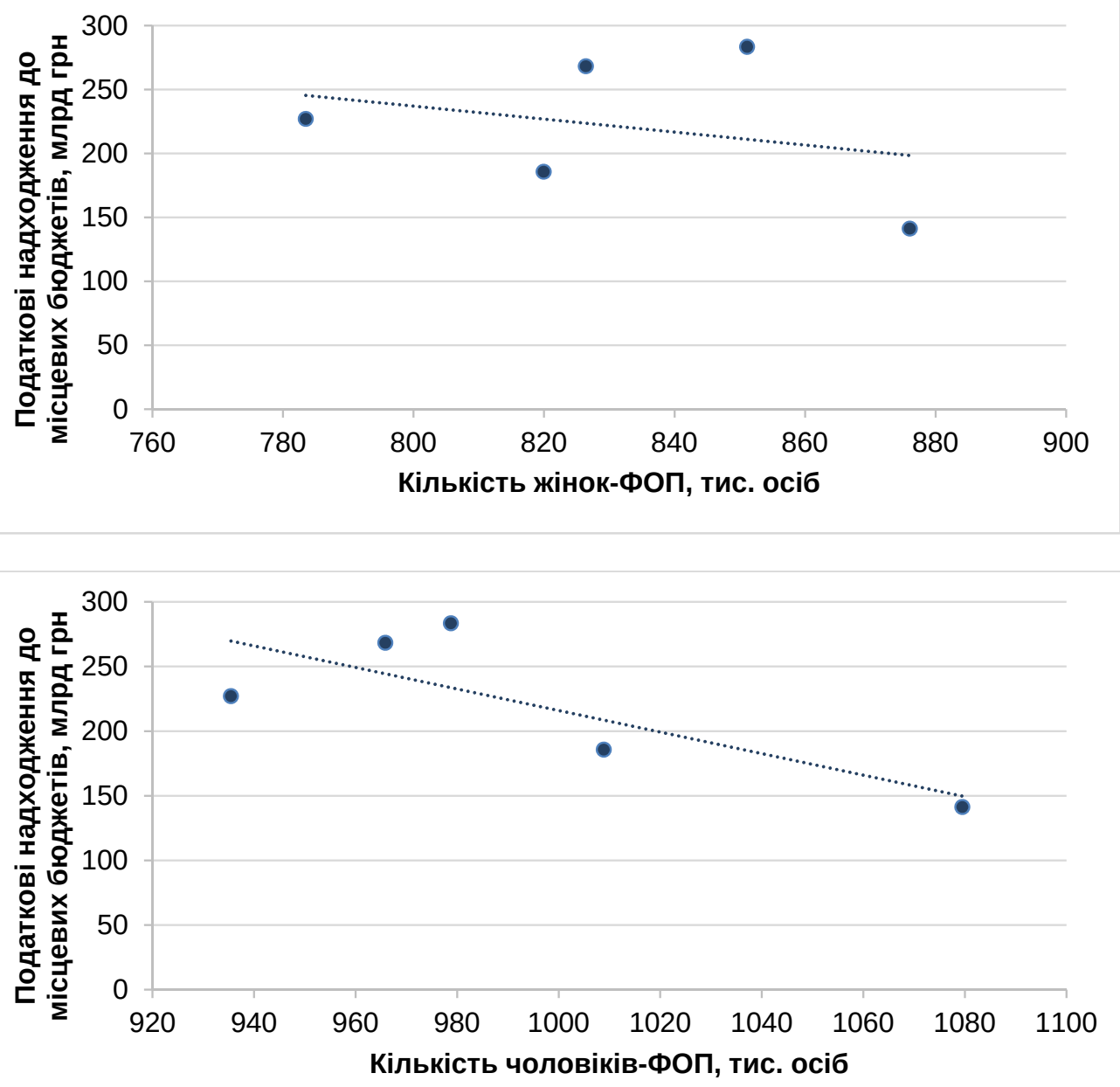

Рис. 4. Залежність податкових надходжень до місцевих бюджетів від кількості жінок - ФОП та чоловіків - ФОП

Джерело: розраховано авторами

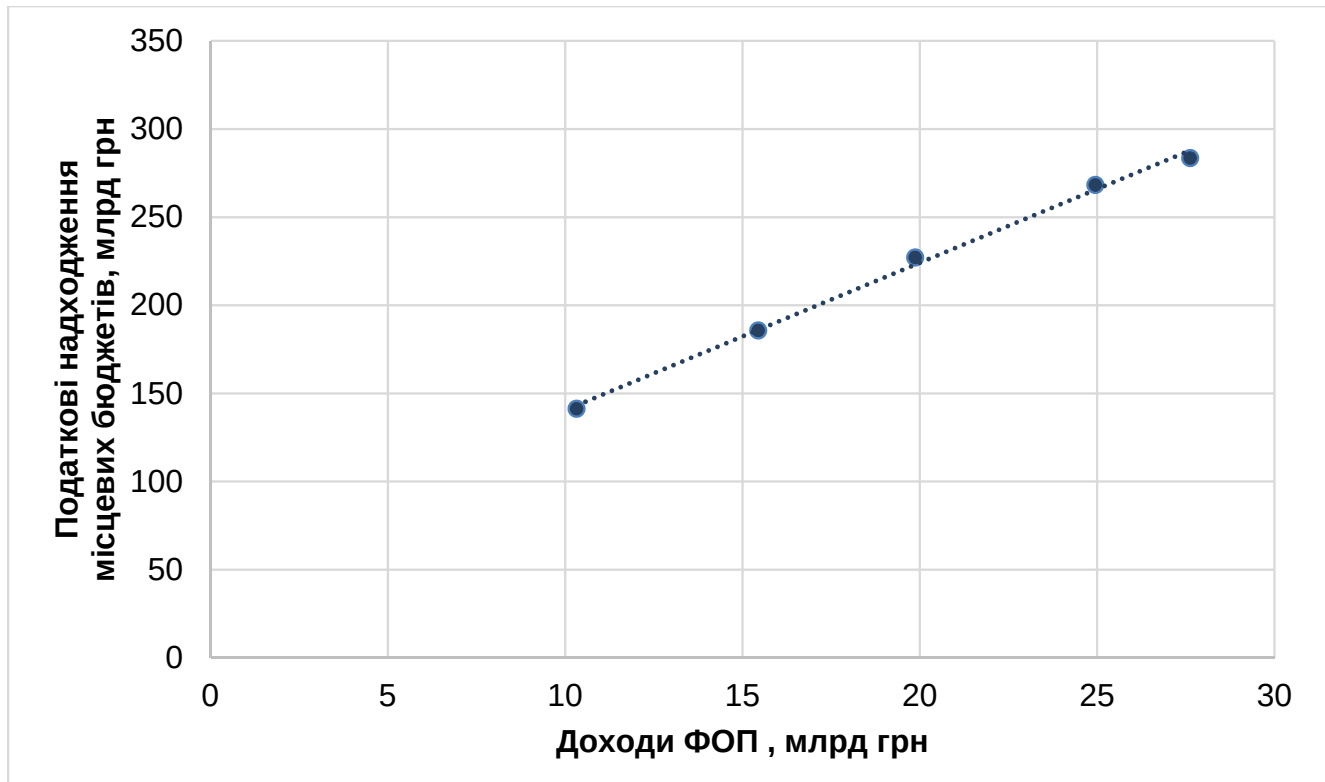

Рис. 5. Залежність податкових надходжень до місцевих бюджетів від доходів ФОП Джерело: розраховано авторами 
дасть змогу підвищити якість планування доходів бюджетів, урахувавши, наприклад, кількість та стать громадян, які мають право на соціальну податкову пільгу або отримують відшкодування податку на доходи фрізичних осіб. Стимулюючи підприємницьку діяльність жінок та створюючи сприятливі умови для роботи жінок із дітьми, можна не тільки вирішити проблему їх працевлаштування, зменшити кількість осіб, які отримують соціальні допомогу, а й сприяти збільшенню надходжень до бюджетів.

Висновки 3 проведеного дослідження. Ключовою позицією для визначення природи ґендерної рівності $€$ розуміння того, що рівний правовий статус не завжди визначає фрактичну рівність, тобто забезпечення рівності прав між чоловіками та жінками не забезпечує автоматично рівних можливостей для їх реалізації в усіх сорерах життя суспільства. Тому досягнення ґендерної рівності вимагає не лише законодавчої бази, а й розуміння складних і часто прихованих фрорм ґендерної нерівності, розуміння її наслідків та прийняття відповідних управлінських рішень.

Застосування ґендерно-орієнтованого підходу в бюджетному процесі дає змогу врахувати ґендерні аспекти у процесі планування, виконання та звітування про виконання бюджетних програм та, відповідно, допомагає усунути ґендерні розриви, ґендерну дискримінацію та негативні тенденції під час надання публічних послуг. Водночас перешкодами на шляху його впровадження стає низка проблем, таких як: відсутність даних, розподілених за статтю, плинність кадрів, відсутність законодавчого забезпечення, складність прийняття управлінських рішень, неприйняття змін, координація між учасниками, обмежене розуміння ҐОБ, недосконале використання програмно-цільового методу.

\section{БІБЛІОГРАФІЧНИЙ СПИСОК:}

1. Коляда Т.А. Гендерно-орієнтоване бюджетування: сутність та перспективи запровадження в Україні. Економічний вісник. Серія: «Фінанси, облік, оподаткування». 2019. Вип. 3. С. 80-88. URL: http://ir.nusta.edu.ua/jspui/handle/doc/4122 (дата звернення: 10.03.2021).

2. Даудова Г.В., Таукешева Т.Д. Упровадження гендерно-орієнтованого бюджетування в Україн Теорія та практика державного управління. 2017. № 2(57). C. 12-19. URL: http://nbuv.gov.ua/UJRN/ Tpdu_2017_2_13 (дата звернення: 11.03.2021).

3. Жінки та чоловіки у Львівській області : статистичний збірник. Львів : Головне управління статистики у Львівській області, 2020. 125 с.

4. Звіт про гендерний аналіз результатів Всеукраїнського опитування щодо дотримання прав BПО. URL: https://ombudsman.gov.ua/images/2018/05/03052018/ Zvit.pdf (дата звернення: 15.03.2021).

5. На карантині працевлаштували менше жінок, ніж чоловіків, - дослідження. URL: https://zmina.info/ news/na-karantyni-praczevlashtuvaly-menshe-zhinokcholovikiv-doslidzhennya/(дата звернення: 13.03.2021).

6. Опендатабот. URL: https://opendatabot.ua/ (дата звернення: 19.03.2021).

7. Орієнтовний перелік показників ґендерної статистики для здійснення оцінки результативності та есрективності стратегій і програм, спрямованих на досягнення ґендерної рівності в. м. Львові.

8. Ооріційний сайт Державної служби статистики України. URL: http://www.ukrstat.gov.ua (дата звернення: 06.04.2021).

9. Офріційний сайт Міністерства фрінансів України. URL: https://mof.gov.ua/uk (дата звернення: 15.03.2021).

10.Права жінок - внутрішньо переміщених осіб як вразливої категорії громадян, що перебувають на особливому контролі Уповноваженого. URL: https://ombudsman.gov.ua/ua/all-news/pr/3518-ej-pra va-zhinok-vnutrishno-peremischenix-osib-yak-vrazlivoiikategoriii/ (дата звернення: 13.03.2021).

11. Ринок праці України, гендерна нерівність та трудова міграція: досвід карантину. URL: https://www.epravda.com.ua/columns/2021/01/15/67 0012/ (дата звернення: 19.03.2021).

12. Sharp R. Budgeting for Equity: Gender Budget Initiatives within a Framework of Performance Oriented Budgeting. URL: http://www.unifem.org/resources/item_ detail (дата звернення: 15.03.2021).

\section{REFERENCES:}

1. Kolyada T.A. (2019) Henderno-oriyentovane byudzhetuvannya: sutnist' ta perspektyvy zaprovadzhennya $v$ Ukrayini [Gender-oriented budgeting: essence and prospects of implementation in Ukraine]. Ekonomichnyy visnyk. Seriya: finansy, oblik, opodatkuvannya, vol. 3, pp. 80-88. Available at: http://ir.nusta.edu.ua/jspui/handle/doc/4122 (accessed 10 March 2021).

2. Daudova H.V., Taukesheva T.D. (2017) Uprovadzhennya henderno-oriyentovanoho byudzhetuvannya v Ukrayini [Introduction of gender-oriented budgeting in Ukraine]. Teoriya ta praktyka derzhavnoho upravlinnya, no. 2(57), pp. 12-19. Available at: http://nbuv.gov.ua/ UJRN/Tpdu_2017_2_13 (accessed 11 March 2021).

3. Zhinky ta choloviky u Lvivskii oblasti: statystychnyi zbirnyk [Women and men in Lviv region: statistical collection]. Lviv: Holovne upravlinnia statystyky u Lvivskii oblasti, 2020. (in Ukrainian)

4. Zvit pro hendernyi analiz rezultativ Vseukrainskoho opytuvannia shchodo dotrymannia prav VPO [Report on Gender Analysis of the Results of the All-Ukrainian Survey on the Observance of the Rights of Internally Displaced Persons]. Available at: https://ombudsman.gov.ua/images/2018/05/03052018/ Zvit.pdf (accessed 15 March 2021).

5. Na karantyni pratsevlashtuvaly menshe zhinok, nizh cholovikiv, - doslidzhennia [Fewer women than men have been employed during Quarantine - research]. Available at: https://zmina.info/news/na-karantyni-prac zevlashtuvaly-menshe-zhinok-nizh-cholovikiv-doslidzhennyal (accessed 10 March 2021).

6. Opendatabot. Available at: https://opendatabot.ua (accessed 10 March 2021). 
7. Oriyentovnyi perelik pokaznykiv gendernoi statystyky dlia zdiysnennia otsinky rezultatyvnosti ta efektyvnosti stratehii i prohram, spryamovanykh na dosyahnennia gendernoi rivnosti $v \mathrm{~m}$. Lvovi [An indicative list of indicators of gender statistics to assess the effectiveness of strategies and programs aimed at achieving gender equality. Lviv].

8. Ofitsiynyi sayt Derzhavnoi sluzhby statystyky Ukrayiny. Available at: http://www.ukrstat.gov.ua (accessed 6 April 2021).

9. Ofitsiynyi sayt Ministerstva finansiv Ukrayiny. Available at: https://mof.gov.ua/uk (accessed 15 March 2021).

10. Prava zhinok - vnutrishno peremishchenykh osib, yak vrazlyvoi katehorii hromadian, perebuvayut na osoblyvomu kontroli Upovnovazhenoho [The rights of women - internally displaced persons, as a vulnerable category of citizens, are under special control of the Commissioner]. Available at: https://ombudsman.gov.ua/ ua/all-news/pr/3518-ej-prava-zhinok-vnutrishno-peremischenix-osib-yak-vrazlivoii-kategoriii/ (accessed 13 March 2021).

11. Rynok pratsi Ukrainy, henderna nerivnist ta trudova mihratsiia: dosvid karantynu [Labor market of Ukraine, gender inequality and labor migration: the experience of quarantine]. Available at: https://www.epravda.com.ua/columns/2021/01/15/67 0012/ (accessed 19 March 2021).

12. Sharp R. Budgeting for Equity: Gender Budget Initiatives within a Framework of Performance Oriented Budgeting. Available at: http://www.unifem.org/ resources/item_detail (accessed 15 March 2021). 